\title{
Amplification of asynchronous inhibition-mediated synchronization by feedback in recurrent networks
}

\author{
Sashi Marella ${ }^{1,2^{*}}, \mathrm{G}$ Bard Ermentrout ${ }^{1,2,3}$ \\ From Nineteenth Annual Computational Neuroscience Meeting: CNS*2010 \\ San Antonio, TX, USA. 24-30 July 2010
}

Theoretical studies of synchronized oscillatory acitivity in the cortex have proposed that principal neuron synchrony can be mediated by short-latency, rapidly-decaying inhibition. However, in the olfactory bulb, the inhibitory granule cells produce long lasting, small amplitude, asynchronous and aperiodic inhibitory input and thus the narrow time window that is required to synchronize spiking does not exist. Instead, it has been suggested that correlated output of the granule cells could synchronize uncoupled mitral cells through stochastic synchronization (SS) [1]. Almost all work on SS presumes that the correlation is imposed and fixed. Building on theory that we and others have developed $[1,2]$, we show that increased synchrony in the mitral cells could produce an increase in granule cell activity for those granule cells that share a synchronous group of mitral cells. Common granule cell input increases the input correlation to the mitral cells and hence their synchrony by providing a positive feedback loop in correlation. Thus we demonstrate the emergence and temporal evolution of input correlation in recurrent networks with feedback. We explore several theoretical models of this idea, ranging from spiking models to an analytically tractable model. The results obtained are used to motivate the investigation of activity in recurrently connected cortical networks containing excitatory pyramidal, inhibitory fast spiking and asynchronously releasing cholecystokininreleasing GABAergic interneurons.

\section{Author details}

${ }^{1}$ Center for Neuroscience, University of Pittsburgh, Pittsburgh, Pennsylvania,15260, USA. ${ }^{2}$ Center for Neural Basis of Cognition, Carnegie Mellon University, Pittsburgh, Pennsylvania, 15260, USA. ${ }^{3}$ Department of Mathematics, University of Pittsburgh, Pittsburgh, Pennsylvania,15260, USA.

Published: 20 July 2010

\footnotetext{
* Correspondence: bard@math.pitt.edu

${ }^{1}$ Center for Neuroscience, University of Pittsburgh, Pittsburgh, Pennsylvania,15260, USA
}

\section{References}

1. Galan RF, Fourcaud-Trocme N, Ermentrout GB, Urban NN: Correlationinduced synchronization of oscillations in olfactory bulb neurons. $J$ Neurosci 2006, 26:3646-3655.

2. Marella S, Ermentrout GB: Class-II neurons display a higher degree of stochastic synchronization than class-I neurons. Phys Rev E Stat Nonlin Soft Matter Phys 2008, 77:041918.

doi:10.1186/1471-2202-11-S1-P20

Cite this article as: Marella and Ermentrout: Amplification of asynchronous inhibition-mediated synchronization by feedback in recurrent networks. BMC Neuroscience 2010 11(Suppl 1):P20.
Submit your next manuscript to BioMed Central and take full advantage of:

- Convenient online submission

- Thorough peer review

- No space constraints or color figure charges

- Immediate publication on acceptance

- Inclusion in PubMed, CAS, Scopus and Google Scholar

- Research which is freely available for redistribution

Submit your manuscript at www.biomedcentral.com/submit
Ciomed Central 